\title{
Occurrence of Sclerotium rolfsii affecting arum lily in Asia
}

\author{
Eisa Nazerian $^{1} \cdot$ Samira Peighami Ashnaei ${ }^{2}$
}

Received: 11 January 2020 / Accepted: 18 January 2021 / Published online: 16 March 2021

(c) Società Italiana di Patologia Vegetale (S.I.Pa.V.) 2021

Keywords Zantedeschia $\cdot$ Sclerotium rolfsii $\cdot$ Ornamental plants

During September 2018, the samples including 18 collars of diseased plants from a sample of approximately 2500 Zantedeschia spp. plants, were collected from the nursery and ornamental plant production centers located in the north of Iran. Pure fungal cultures were obtained using hyphal tip method. In pathogenicity assays, wounded basal stems of potted plants were inoculated by mycelium plugs of three isolates with three replications. Control plants were inoculated using sterile PDA plaques without the fungus. Re-isolation of the fungus was performed to fulfil Koch's postulates. Disease symptoms appeared as yellowing and dropping of leaves, wilting of plants and the formation of a thin epiphytic white cottony mycelial growth at the collar region. Small brown spherical sclerotia, associated with the rotting tissue, were observed on the collars of diseased plants. The morphological appearance of the fungus included the following. Hyphae: white, branched, 1.4-2.8 $\mu \mathrm{m}$ diameters, with clamp connections; sclerotia: smooth, spherical to ellipsoidal, light brown becoming dark brown with age, 0.6-2.0 mm diameter. Blast searches of the GenBank nucleotide database revealed $98 \%$ identity to Athelia rolfsii (Sclerotium rolfsii KT222899). The sequence of $S$. rolfsii isolate was deposited in GenBank (MK182755). To the best of our knowledge, this is the first study in Asia to determine basal rot disease in Z. aethiopica caused by S. rolfsii. The disease referred to as "Basal Rot" of Z. aethiopica was previously reported in the United States and Brazil (Farr et al. 1989; Mesquita et al. 2007).

Eisa Nazerian

eisanazerian1144@gmail.com

1 Education and Extension Organization of Jihad-EAgriculture, Iranian Horticultural Research Institute, Flower and Ornamental Plants Research Center of Iran, Mahalat, Iran

2 Plant Disease Research Department, AgriculturalResearchEducationandExtension Organization(AREEO), Iranian Research Institute of Plant Protection, Tehran, Iran

\section{References}

Farr DF, Bills GF, Chamuris GP, Rossman AY (1989) Fungi on plants and products in the United States. APS Press: St Paul, MN 101(7-8):340

Mesquita ER, Pereira OL, Grossi JA (2007) Basal rot of arum lily (Zantedeschia aethiopica) caused by Sclerotium rolfsii in Brazil. Australas Plant Dis Notes 2:91-92 